\title{
Risk Assessment of Trace Metals in Soils in the Vicinity of NPA Expressway Open Dump in Warri Metropolis, Delta State, Nigeria
}

\author{
Helen Ataikiru1 ${ }^{*}$, Felix E. Okieimen² \\ ${ }^{1}$ College of Education, Warri, Nigeria \\ ${ }^{2}$ Department of Chemistry, University of Benin, Benin City, Nigeria \\ Email: *ataikiru@yahoo.com
}

How to cite this paper: Ataikiru, H. and Okieimen, F.E. (2019) Risk Assessment of Trace Metals in Soils in the Vicinity of NPA Expressway Open Dump in Warri Metropolis, Delta State, Nigeria. Journal of Environmental Protection, 10, 562-576. https://doi.org/10.4236/jep.2019.104032

Received: December 28, 2018

Accepted: April 12, 2019

Published: April 15, 2019

Copyright $\odot 2019$ by author(s) and Scientific Research Publishing Inc. This work is licensed under the Creative Commons Attribution International License (CC BY 4.0).

http://creativecommons.org/licenses/by/4.0/

\begin{abstract}
Heavy metals are non-biodegradable. They accumulate in the environment and subsequently contaminate the food chain. It is therefore essential to monitor heavy metals content in the soil, so as to prevent too much accumulation in human beings and animals through food chain. Test soil samples were collected from Nigeria Ports Authority (NPA) Expressway open dump, and background (control) soil samples were also collected at about $2 \mathrm{~km}$ from the open dump and spatial test samples were also collected. The physicochemical properties of the soil were determined. Tessier's sequential extraction protocols were used to assess the geochemical forms of $\mathrm{Cr}, \mathrm{Pb}, \mathrm{Zn}$, and $\mathrm{Mn}$ in the soil of the open dump. The concentrations of the heavy metals in the extracts were determined in a pre-calibrated atomic absorption spectrophotometer and they are above the background sample values. The metal assessment index (Igeo) evaluated, indicated that the soil in the vicinity of the open dump was highly polluted. The results obtained showed the mobile metal pools which are available to plants roots.
\end{abstract}

\section{Keywords}

Contamination, Risk, Assessment, Soil, Heavy Metals, Dump

\section{Introduction}

Pollution by heavy metals occurs largely from industrial, domestic and agricultural wastes as well as from combustion of fossil fuel by automobiles and industries [1].

Warri is a beehive of commercial and industrial activities. There are major industries in Warri metropolis and also numerous shops, markets and schools, 
which generate both degradable and non-degradable solid wastes. These wastes are comprised of paper, metals, glass, plastics, wood, rag, rubber, leather, food, scraps, damaged bicycles, coins, stainless steel, zinc roofing sheets, computer monitors, printer wiring board (PWB), relays, switch, broken mercury thermometer, dental amalgams, fluorescence lamps, etc. They decay and break into small pieces, are mineralized overtime and release their metallic contents into the soil. Soil pollution is caused by misuse of the soil, such as poor agricultural practices, disposal of industrial and urban wastes [2]. Excess heavy metals accumulation in the environment is capable of having toxicological implication in humans and other animals [1]. Soils are often recipient of pollutants from diverse sources, such as industrial emissions, waste disposal sites, agriculture, urban centers and vehicular emissions among others depending on its location [3]. Contaminants from all these sources are quickly transferred to air, water and soil [4]. Heavy metals although often ubiquitous and present in environment at low concentrations may pose human health risk when their concentrations reach levels above the permissible limits as stipulated by national and international regulatory bodies based on scientific evidence [4]-[9]. Heavy metal contamination poses a risk to the environment and human health [10].

Therefore, the study aimed at assessing the heavy metal hazard potentials of the soil from NPA Expressway open dump by determining the varying concentrations of the toxic metals constituents and evaluating the mobile forms of the metals.

Different types of indices are used to assess the pollution status of soil/sediment and select the best index to describe the soil quality. Some of the indices used are geoaccumulation index (Igeo) and metal mobility factor (MF).

\subsection{Geoaccumulation Index}

The Geoaccumulation index (Igeo) introduced by Muller in 1979 was used to assess metal pollution in soil/sediments [11]. Geoaccumulation index is expressed as in the equation below:

$$
\text { Igeo }=\log _{2}(\mathrm{Cn} / 1.5 \mathrm{Bn})
$$

The geoaccumulation index includes seven grades.

It includes various degrees of enrichment above the background value, ranging from unpolluted to very highly polluted soil/sediment quality.

The highest grade (class six) reflects 100 -fold enrichment above the background values [12].

\subsection{Geoaccumulation Index of Heavy Metal Concentration in Soil}

\begin{tabular}{ccc}
\hline Geoaccumulation Index & Class & Contamination Degree (Cdeg) \\
\hline 0 & 0 & Background concentration \\
$0-1$ & 1 & Unpolluted \\
$1-2$ & 2 & Moderately unpolluted \\
\hline
\end{tabular}


Continued

\begin{tabular}{ccc}
\hline $2-3$ & 3 & Moderately polluted \\
$3-4$ & 4 & Moderately highly polluted \\
$1-5$ & 5 & Highly polluted \\
$<5$ & 6 & Very highly polluted
\end{tabular}

Source: Singh et al. (2003) [12].

\subsection{Intervention Values}

Intervention Values indicate the quality for which the functionality of soil for human, animal and plant life are threatened with being seriously impaired or are being impaired. Concentration levels in excess of the intervention values correspond to serious contamination. Intervention values are soil-type specific in that it relates to the content of organic matter and clay in the soil of concern.

Trace metals may be distributed or fractionated among many components of the soil and may be associated with them in different ways. Chemical speciation is defined as distribution of an individual chemical element among different species or groups.

Tessier's extraction scheme allows the division of the total metal content into five fractions: Exchangeable bound, carbonate bound, iron/manganese oxide bound, organic matter bound and residual fraction [13]. Tessier's method is selected since it allows suitable estimation about characteristics of metal association [13]. It evaluates both the actual and potential mobility of metals in the environment. Each fraction obtained by the sequential procedure contains a different form of associated metal in soils.

The relative index of metal mobility is calculated as mobility factor [14] using the different fractions in the equation below.

$$
\mathrm{MF}=\frac{\mathrm{F}_{1}+\mathrm{F}_{2}}{\mathrm{~F}_{1}+\mathrm{F}_{2}+\mathrm{F}_{3}+\mathrm{F}_{4}+\mathrm{F}_{5}} \times 100
$$

The mobility of metals in soil is assessed on the basis of absolute and relative content of fractions weakly bound to soil components.

High MF values are symptoms of relatively high lability and biological availability of heavy metals in soils to plants and other ecological receptors.

\section{Purpose of the Study}

The purpose of this study is to evaluate the contribution of solid wastes to heavy metal pollution of the urban soils of Warri. This is because the plant crops growing close to such open dumps will be harvested for food or for sale to the public by the owner of the land, and heavy metals will be transferred by food chain to man. The NPA expressway open dump was chosen as it is one of the popular dump sites in the city of Warri.

\section{Objectives of the Study}

This work is set to: 
1) Measure the total concentration levels of heavy metals in soils in the vicinity of NPA Expressway open dump in Warri.

2) Evaluate anthropogenic pollution status of the soil in the vicinity of the open dump using the geoaccumulation index.

3) Determine the chemical forms of the heavy metals in the soil samples in the NPA Expressway open dump using sequential extraction technique.

4) Determine the spatial distribution of the heavy metals in the soil samples in the vicinity of the open dump.

5) Evaluate the mobile metal forms of the heavy metals of environmental concerns.

\section{Experimental}

\subsection{Study Site}

Figure 1 below shows the geographical location of Warri in the map of Nigeria and Figure 2 shows the NPA Expressway open dump.

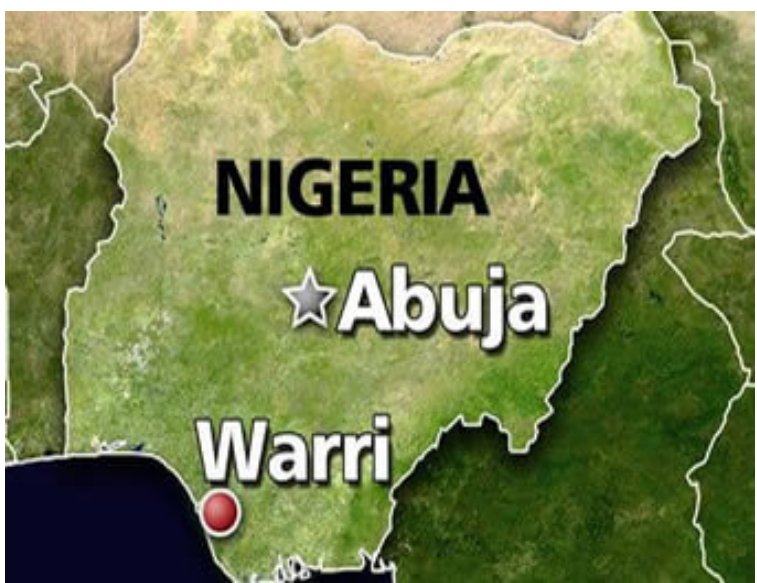

Figure 1. Geographical location of Warri in the Map of Nigeria. https://www.tribuneonlineng.com.

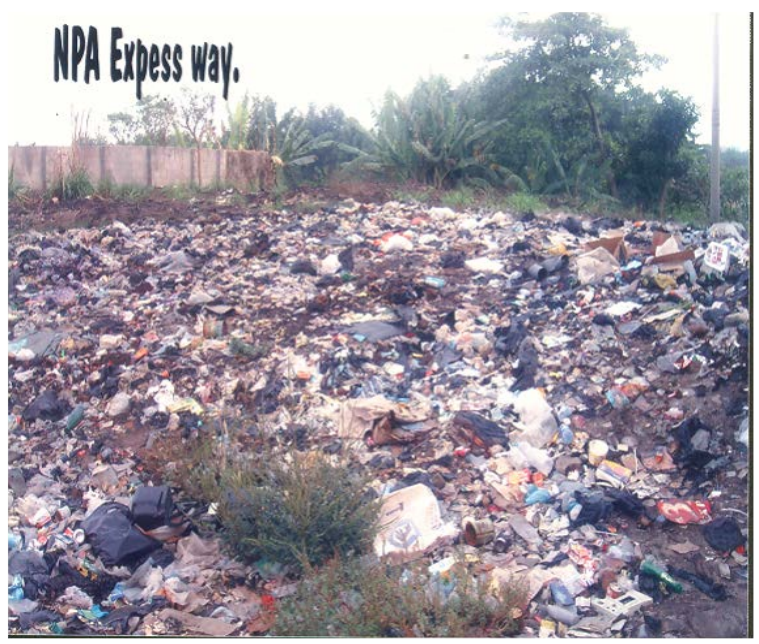

Figure 2. NPA Expressway open dumpsite. 


\subsubsection{Sampling Location}

Warri metropolis is the headquarters of Warri South Local Government Area. Warri is situated in the Southern part of Delta State precisely about the intersection of longitude $5.45^{\circ}$ East and latitude $5.30^{\circ}$ North of the Equator. Warri is about 256 square kilometres in Area, with a total population of 303,417 [15]. NPA open dump is located west of the city.

\subsubsection{Sampling}

\section{1) Aggregate Test Soil Samples of NPA Expressway Open Dump}

Aggregate soil samples were collected from NPA Expressway open dump using a stainless steel auger.

Background (control) soil samples were also collected at about $2 \mathrm{~km}$ from the open dump. The background samples are the control samples which are collected far away from the open dump to avoid possible contamination of the soil.

\section{2) Spatial Test Soil Samples}

Spatial test samples were collected at various increasing distances $10 \mathrm{~m}-109$ $\mathrm{m}$ from the open dump. Sampling was done in the wet season.

\subsection{Method}

\subsubsection{Preparation of Soil Samples for Analysis}

The soil samples were air dried, ground and sieved through a $2 \mathrm{~mm}$ sieve. Dried soil samples that fell below the sieve were stored in polythene bags and properly labeled for subsequent analyses. They were used for all the analyses. The total heavy metal concentrations of the test soil and background soil samples were determined using the procedure described by Tessier et al., 1979 [13]. The resulting solution was analyzed using an Atomic absorption spectrophotometer.

\subsubsection{Determination of Physico-Chemical Properties of the Soil Samples} The physico-chemical properties, $\mathrm{pH}, \mathrm{TOC}, \mathrm{CEC}$, the soil textural class and the total metal content of the soil samples were determined using standard procedures/methods.

\subsubsection{The Soil pH}

$20 \mathrm{~g}$ of soil sample was weighed into a $50 \mathrm{ml}$ beaker and $20 \mathrm{ml}$ distilled water was added. The soil/water mixture (ratio 1:1) was allowed to stand for 30 minutes and stirred occasionally with a glass rod. The Suntex $\mathrm{pH}$ meter was calibrated using buffer 4 and 7 . The electrodes were rinsed and subsequently immersed into the soil/water mixture and the $\mathrm{pH}$ was recorded as $\mathrm{pH}\left(\mathrm{H}_{2} 0\right)$ [16].

\subsubsection{Total Organic Carbon}

$5 \mathrm{ml}$ of $\mathrm{K}_{2} \mathrm{Cr}_{2} \mathrm{O}_{7}$ solution was added to one gram soil sample in a $250 \mathrm{ml}$ Erlenmeyer flask and swirled gently to wet the sample thoroughly. $20 \mathrm{ml}$ of concentrated $\mathrm{H}_{2} \mathrm{SO}_{4}$ was then added and the mixture was allowed to cool. $100 \mathrm{ml}$ of distilled water was added, followed by few drops of ferrion indicator and the mixture was titrated against $0.5 \mathrm{M}$ iron (II) sulphate solution to a green endpoint. A blank determination was also performed. The blank contained $5 \mathrm{ml}$ of the $\mathrm{K}_{2} \mathrm{Cr}_{2} \mathrm{O}_{7}$ 
solution, $20 \mathrm{ml}$ concentrated $\mathrm{H}_{2} \mathrm{SO}_{4}, 100 \mathrm{ml}$ distilled water and 5 drops of Ferroin indicator [17] [18].

\subsubsection{Calculation}

$$
\% \text { Organic carbon }=\frac{(B-T) \times M \times 0.003 \times 1.33 \times 100}{W}
$$

$B=$ Blank titer $(\mathrm{ml})$

$T=$ Sample titer $(\mathrm{ml})$

$M=$ Molarity of Iron (II) sulphate

$0.003=$ Factor for equivalent weight of carbon

1.33 = Factor for proportion of active organic carbon

$W=$ Weight of soil $(1 \mathrm{~g})$

$\%$ organic matter in soil $=\%$ organic carbon $\times 1.729$.

\subsubsection{Cation Exchange Capacity}

$5 \mathrm{~g}$ of soil sample was weighed into a $250 \mathrm{ml}$ polypropylene bottle and $100 \mathrm{ml} 5$ $\mathrm{M} \mathrm{NH}_{4} \mathrm{OAc}$ solution added. The mixture was shaken 30 mins in a mechanical shaker (Heldoph) at $200 \mathrm{rpm}$ for 30 mins. The supernatant was filtered through Whatman No. 1 filter paper. The concentration of $\mathrm{K}^{+}$and $\mathrm{Na}^{+}$in the extract were determined by flame photometer while $\mathrm{Mg}^{2+}$ and $\mathrm{Ca}^{2+}$ were determined using Atomic Absorption Spectrophotometer (Buck Scientific VGP 210 model). The equipment was calibrated using various concentrations of the metals ranging from $2-20 \mathrm{ppm}$ prepared from analytical grade reagents (Sigma, BDH and Buck Scientific). The summation of the various cations was reported as cation exchange capacity [19].

\subsubsection{Particle Size Analysis-Hydrometer Method}

$50 \mathrm{~g}$ of soil sample was weighed into a $250 \mathrm{ml}$ beaker, $100 \mathrm{ml}$ distilled water and $10 \mathrm{ml}$ of concentrated $\mathrm{H}_{2} \mathrm{O}_{2}$ were added to the soil. The content of the beaker was heated until frothing stopped. The mixture was cooled and transferred into shaking bottles, $20 \mathrm{ml}$ of sodium hexametaphosphate solution was added and mixture shaken for $1 \mathrm{hr}$. The suspension was transferred to $1 \mathrm{~L}$ sedimentation cylinder and brought to mark with water. A plunger was used to agitate the suspension. The hydrometer was then lowered into the suspension and its reading was taken after 40 seconds. The temperature was noted. The first reading, $R_{1}$, gave the percentage clay and silt. The suspension was allowed to stand for 2 hours before the hydrometer reading was taken again. The second reading, $R_{2}$, gave the percentage clay [20] [21].

Calculation

$$
\begin{gathered}
\%(\text { Clay }+ \text { Silt })=\frac{R_{1}+0.3 x \times 100}{\text { Dry Weight of soil }} \\
\% \text { Clay }=\frac{R_{2}+0.3 x \times 100}{W}
\end{gathered}
$$

$R_{1}=$ Hydrometer reading after 40 seconds. 
$R_{2}=$ Hydrometer reading after 2 hours.

$X=$ Degree rise above calibration point of hydrometer

0.3 = Correction factor for every degree rise above the calibration temperature of the hydrometer.

$W=$ Weight of soil sample $(50 \mathrm{~g})$.

$$
\begin{aligned}
& \% \text { sand }=100-(\text { Clay }+ \text { Silt }) \% \\
& \% \text { Silt }=100-(\text { Sand }+ \text { Clay }) \%
\end{aligned}
$$

\subsubsection{Geochemical Forms of $\mathrm{Cr}, \mathrm{Pb}, \mathrm{Zn}$ and $\mathrm{Mn}$ in the Soil Samples}

In order to assess the geochemical forms and bioavailability ( $\mathrm{Cr}, \mathrm{Pb}, \mathrm{Zn}$ and $\mathrm{Mn}$ ) in the soil of the open dumps, Tessier et al., (1979) [13] sequential extraction procedures were employed.

$1 \mathrm{~g}$ of each of the soil samples was used for the sequential extraction. After each successive extraction process, centrifuging the mixture at $1500 \mathrm{rpm}$ for 15 mins affected the liquid-solid phase separation. The supernatant was decanted into a polypropylene bottle for metal analysis while the residue was carried through the whole extraction process.

The concentrations of heavy metals $(\mathrm{Cr}, \mathrm{Pb}, \mathrm{Zn}$ and $\mathrm{Mn})$ in the various extracts were determined in a pre-calibrated atomic absorption spectrophotometer.

\subsubsection{Tessier et al. Sequential Extraction of $\mathrm{Cr}, \mathrm{Pb}, \mathrm{Zn}$ and $\mathrm{Mn}$ in Soil Samples at the Vicinity of the Open Dump}

Exchangeable $\left(\mathrm{F}_{1}\right)$ : The residue from above is extracted with $8 \mathrm{ml} 1 \mathrm{M} \mathrm{MgCl}_{2}$ (pH7) for 1 hour.

Carbonate Bound $\left(\mathrm{F}_{2}\right)$ : The residue from $\left(\mathrm{F}_{1}\right)$ extracted with $8 \mathrm{ml} 5 \mathrm{M} \mathrm{NaOAC}$ (pH5) for 5 hours.

$\mathrm{Fe}-\mathrm{Mn}$ Oxide bound $\left(\mathrm{F}_{3}\right)$ : The residue from $\left(\mathrm{F}_{2}\right)$ extracted with $0.04 \mathrm{M}$ $\mathrm{NH}_{2} \mathrm{OH}$. $\mathrm{HC} 1$ for 6 hours at $96^{\circ} \mathrm{C} \pm 2^{\circ} \mathrm{C}$.

Organic matter bound $\left(\mathrm{F}_{4}\right)$ : The residue from $\left(\mathrm{F}_{3}\right)$ extracted with $30 \% \mathrm{H}_{2} \mathrm{O}_{2}$ (pH2), $3.6 \mathrm{M} \mathrm{NH}_{4} \mathrm{OAC}$ for 5 hours +30 mins at $85^{\circ} \mathrm{C} \pm 2^{\circ} \mathrm{C}$.

Residual $\left(\mathrm{F}_{5}\right)$ : The residue from $\left(\mathrm{F}_{4}\right)$ extracted with Aqua-regia, $\mathrm{HC} \mathrm{O}_{4}$ until white fumes appeared.

\subsubsection{Quality Control and Assurance}

In order to ensure the accuracy and reliability of the results obtained, all reagents used for the preparation of standard solutions and analysis were analytical grades (BDH, Sigma and Buck Scientific).

All glass wares and plastics were acid-washed and rinsed thoroughly with deionized water.

Buck scientific standard solutions were used to calibrate the atomic absorption spectrophotometer as required. Buck scientific (VGP210) atomic absorption spectrophotometer was used for the analyses.

Procedural blank samples were subjected to similar extraction method using the same amounts of reagents. Blank determinations of the elements were below 
the detection limits of the atomic absorption spectrophotometer.

The analyses were carried out in triplicates.

\subsection{Statistical Analysis}

The analytical results were compiled to form a multi-element data base using excel.

\section{Results and Discussion}

Tables 1-4 and Figure 3 below showed the results obtained.

The physicochemical properties of the soil samples from NPA Expressway open dump showed that the soil is predominantly sandy loam - $57.00 \% \pm 2.00 \%$ being sand, $27.00 \% \pm 2.00 \%$ being silt. Clay is made up of $16.00 \% \pm 2.00 \%$ as shown in Table 1 below. The soil type is a characteristic of a well-drained soil rendering the soil permeable to pollutants including heavy metals.

Table 1. Physicochemical properties of aggregate soil samples from NPA Expressway open dump in Warri, Delta State.

\begin{tabular}{cc}
\hline Physicochemical Parameters & NPA Expressway Open Dump \\
\hline PH & $6.92 \pm 0.03$ \\
TOC (\%) & $9.83 \pm 0.67$ \\
CEC (Meq/100 $\mathrm{mg})$ & $15.56 \pm 2.10$ \\
Sand (\%) & $57.00 \pm 2.00$ \\
Clay (\%) & $16.00 \pm 2.00$ \\
Silt (\%) & $27.00 \pm 2.00$ \\
Textural Class & Sandy loam \\
Total metal content $(\mathrm{Mg} / \mathrm{Kg})$ & \\
$\mathrm{Cr}$ & $292.28 \pm 7.82$ \\
$\mathrm{~Pb}$ & $10.00 \pm 2.00$ \\
$\mathrm{Zn}$ & $456.00 \pm 5.00$ \\
$\mathrm{Mn}$ & $111.00 \pm 7.00$ \\
\hline
\end{tabular}

Table 2. Mean values of $\mathrm{Cr}, \mathrm{Pb}, \mathrm{Zn}$ and $\mathrm{Mn}$ contents in the aggregate soil samples of NPA Expressway open dump, background soil sample values ( $\mathrm{mg} / \mathrm{kg}$ of soil dry weight), intervention values and uncontaminated soil values from around the world.

\begin{tabular}{ccccc}
\hline Metals & Mean values of heavy metal content $(\mathrm{mg} / \mathrm{kg})$ & & \\
\hline & $\begin{array}{c}\text { NPA Expressway } \\
\text { sample values }\end{array}$ & $\begin{array}{c}\text { Background } \\
\text { sample values }\end{array}$ & $\begin{array}{c}\text { Intervention } \\
\text { values }\end{array}$ & $\begin{array}{c}\text { Uncontaminated } \\
\text { soil values }\end{array}$ \\
\hline $\mathrm{Cr}$ & $292.28 \pm 7.82$ & $1.80 \pm 0.20$ & 190.4 & 100 \\
$\mathrm{~Pb}$ & $10.00 \pm 2.00$ & $1.00 \pm 0.04$ & 312 & 14 \\
$\mathrm{Zn}$ & $456.00 \pm 5.00$ & $3.80 \pm 0.80$ & 257.5 & 75 \\
$\mathrm{Mn}$ & $111.00 \pm 7.00$ & $5.00 \pm 0.30$ & $\mathrm{NL}$ & 960
\end{tabular}

Uncontaminated soil values from around the world [22]. NL is not listed in DPR target and intervention values for micro pollutant for a standard soil [23]. 
Table 3. Spatial distribution of the total metal content $(\mathrm{mg} / \mathrm{kg})$, standard deviation and background sample values of $\mathrm{Cr}, \mathrm{Pb}, \mathrm{Zn}$ and Mn in soil of NPA Expressway open dump, Warri.

\begin{tabular}{|c|c|c|c|c|c|c|c|c|c|}
\hline $\begin{array}{l}\text { Metals } \\
(\mathrm{mg} / \mathrm{kg})\end{array}$ & $10 \mathrm{~m}$ & $11 \mathrm{~m}$ & $12 \mathrm{~m}$ & $13 \mathrm{~m}$ & $14 \mathrm{~m}$ & $29 \mathrm{~m}$ & $59 \mathrm{~m}$ & $109 \mathrm{~m}$ & $\begin{array}{c}\text { Background } \\
\text { values }\end{array}$ \\
\hline $\mathrm{Cr}$ & $234.00 \pm 1.00$ & $208.20 \pm 10.00$ & $184.00 \pm 5.00$ & $158.00 \pm 0.00$ & $111.00 \pm 2.00$ & $20.00 \pm 4.00$ & $18.00 \pm 3.70$ & $14.80 \pm 2.80$ & $1.80 \pm 0.20$ \\
\hline $\mathrm{Pb}$ & $7.20 \pm 1.00$ & $5.90 \pm 1.00$ & $3.20 \pm 0.80$ & $1.90 \pm 0.80$ & $1.20 \pm 0.10$ & $1.10 \pm 0.00$ & $1.10 \pm 0.20$ & $1.10 \pm 0.40$ & $1.00 \pm 0.04$ \\
\hline $\mathrm{Zn}$ & $396.80 \pm 9.00$ & $301.00 \pm 6.00$ & $233.20 \pm 5.00$ & $134.10 \pm 12.00$ & $76.00 \pm 10.00$ & $23.80 \pm 5.20$ & $19.60 \pm 3.60$ & $15.00 \pm 3.00$ & $3.80 \pm 0.80$ \\
\hline
\end{tabular}

Table 4. Spatial Contamination Profile of the heavy metals in the vicinity of NPA Expressway open dump.

\begin{tabular}{|c|c|c|c|}
\hline $\begin{array}{l}\text { Distances from epicentre } \\
\text { of the open dump (m) }\end{array}$ & Metals & $\begin{array}{l}\text { Geoaccumulation } \\
\text { Index (Igeo) }\end{array}$ & Pollution status \\
\hline \multirow{4}{*}{10} & $\mathrm{Cr}$ & 6.4 & Very highly polluted \\
\hline & $\mathrm{Pb}$ & 2.3 & Moderately polluted \\
\hline & $\mathrm{Zn}$ & 6.1 & Very highly polluted \\
\hline & $\mathrm{Mn}$ & 3.8 & Moderately highly polluted \\
\hline \multirow{4}{*}{11} & $\mathrm{Cr}$ & 6.3 & Very highly polluted \\
\hline & $\mathrm{Pb}$ & 2.0 & Moderately unpolluted \\
\hline & $\mathrm{Zn}$ & 5.7 & Very highly polluted \\
\hline & $\mathrm{Mn}$ & 3.6 & Moderately highly polluted \\
\hline \multirow{4}{*}{12} & $\mathrm{Cr}$ & 6.1 & Very highly polluted \\
\hline & $\mathrm{Pb}$ & 1.1 & Moderately to unpolluted \\
\hline & $\mathrm{Zn}$ & 5.4 & Very highly polluted \\
\hline & $\mathrm{Mn}$ & 3.8 & Moderately highly polluted \\
\hline \multirow{4}{*}{13} & $\mathrm{Cr}$ & 5.9 & Very highly polluted \\
\hline & $\mathrm{Pb}$ & 0.3 & Unpolluted \\
\hline & $\mathrm{Zn}$ & 4.6 & Highly polluted \\
\hline & $\mathrm{Mn}$ & 3.5 & Moderately highly polluted \\
\hline \multirow{4}{*}{14} & $\mathrm{Cr}$ & 5.4 & Very highly polluted \\
\hline & $\mathrm{Pb}$ & -0.3 & Background concentration \\
\hline & $\mathrm{Zn}$ & 3.7 & Moderately highly polluted \\
\hline & $\mathrm{Mn}$ & 2.9 & Moderately polluted \\
\hline \multirow{4}{*}{29} & $\mathrm{Cr}$ & 2.9 & Moderately polluted \\
\hline & $\mathrm{Pb}$ & -0.6 & Background concentration \\
\hline & $\mathrm{Zn}$ & 2.1 & Moderately polluted \\
\hline & $\mathrm{Mn}$ & 1.7 & Moderately unpolluted \\
\hline \multirow{4}{*}{59} & $\mathrm{Cr}$ & 2.7 & Moderately polluted \\
\hline & $\mathrm{Pb}$ & -1.3 & Background concentration \\
\hline & $\mathrm{Zn}$ & 1.8 & Moderately unpolluted \\
\hline & $\mathrm{Mn}$ & 1.7 & Moderately unpolluted \\
\hline \multirow{4}{*}{109} & $\mathrm{Cr}$ & 2.5 & Moderately polluted \\
\hline & $\mathrm{Pb}$ & -0.5 & Background concentration \\
\hline & $\mathrm{Zn}$ & 1.4 & Moderately unpolluted \\
\hline & $\mathrm{Mn}$ & 1.4 & Moderately unpolluted \\
\hline
\end{tabular}

Table 2 above shows that the total metal contents of $\mathrm{Cr}, \mathrm{Pb}, \mathrm{Zn}$ and $\mathrm{Mn}$ in the aggregate soil samples are above the background soil sample values.

The mean values of $\mathrm{Cr}$ and $\mathrm{Zn}$ exceeded the 190.4 and 257.5 intervention values 




Figure 3. Distribution pattern of $\mathrm{Cr}, \mathrm{Pb}, \mathrm{Zn}$ and $\mathrm{Mn}$ in the aggregate soil samples of NPA Expressway Open Dump in Warri.

respectively, and the $100 \mathrm{mg} / \mathrm{kg}$ and $75 \mathrm{mg} / \mathrm{kg}$ values respectively stated for uncontaminated soil from around the world [22]. Concentration levels in excess of the intervention values correspond to serious contamination.

The high values of $\mathrm{Cr}$ and $\mathrm{Zn}$ may be associated with anthropogenic activities ranging from the waste disposal into the open dump, vehicular emissions and particulate matter while the low value of $\mathrm{Pb}$ may be due to the fact that NPA Expressway is far from human settlement as a result $\mathrm{Pb}$ containing materials are few in the open dump. Atmospheric deposition may have contributed to the amount determined.

The total metal content determined as shown in Table 3 above indicated that the levels of $\mathrm{Cr}, \mathrm{Pb}, \mathrm{Zn}$ and $\mathrm{Mn}$ in all the distances are above the background sample values except for $\mathrm{Pb}$ at distance $59 \mathrm{~m}$. In addition, the total metal content determined also indicated that the levels of $\mathrm{Cr}$ and $\mathrm{Zn}$ at distances $(10 \mathrm{~m}-14 \mathrm{~m})$ away from the epicentre of the open dump are above the $100 \mathrm{mg} / \mathrm{kg}$ and 75 $\mathrm{mg} / \mathrm{kg}$ values stated for uncontaminated soils respectively.

The levels of Lead and Manganese in all the distances (10 m - $109 \mathrm{~m})$ away from the epicentre of the open dump are below the $14 \mathrm{mg} / \mathrm{kg}$ and $960 \mathrm{mg} / \mathrm{kg}$ values for uncontaminated soils from around the world as in Table 2 above.

The spatial variation of $\mathrm{Cr}, \mathrm{Pb}, \mathrm{Zn}$ and $\mathrm{Mn}$ as in Table 3 indicated that the soil samples collected $10 \mathrm{~m}$ away from the epicentre of the open dump had the highest levels of $\mathrm{Cr}(234.00 \mathrm{mg} / \mathrm{kg}), \mathrm{Pb}(7.20 \pm 1.00 \mathrm{mg} / \mathrm{kg}), \mathrm{Zn}(396.80 \mathrm{mg} / \mathrm{kg}), \mathrm{Mn}$ $(104.00 \mathrm{mg} / \mathrm{kg}$ ) while the soil samples collected $109 \mathrm{~m}$ away from the epicentre of the open dump had the lowest concentration levels of $\mathrm{Cr}(14.80 \pm 2.80 \mathrm{mg} / \mathrm{kg})$, $\mathrm{Pb}(1.10 \pm 0.40 \mathrm{mg} / \mathrm{kg}), \mathrm{Zn}(15.00 \pm 3.00 \mathrm{mg} / \mathrm{kg})$ and $\mathrm{Mn}(20.00 \pm 0.00 \mathrm{mg} / \mathrm{kg})$, this shows that the heavy metal content decreases as the distance increases and becomes far away from the open dump which is the source of the pollution. The study conducted by Ahmed et al. [24] at two municipal solid wastes (MSW) dumpsites at Alexandria in Egypt also showed similar trend of heavy metal contamination in soils.

At distance $59 \mathrm{~m}$ away from the epicentre of NPA Expressway open dump, 
Mtotal was $61.60 \pm 10.50 \mathrm{mg} / \mathrm{kg}$ (and contained Cr: $18.00 \pm 3.70 \mathrm{mg} / \mathrm{kg}, \mathrm{Pb}: 0.6$ $\pm 0.20 \mathrm{mg} / \mathrm{kg}, \mathrm{Zn}: 19.60 \pm 3.60 \mathrm{mg} / \mathrm{kg}$ and $\mathrm{Mn}: 24.40 \pm 3.00 \mathrm{mg} / \mathrm{kg})$, suggesting a spatial reduction in $\mathrm{M}$ total of about $97.7 \%$.

The metal assessment index (Igeo) used to assess the contamination status of the soil of the NPA Expressway open dump as shown in Table 4 above indicated that the geoaccumulation index (Igeo) ranged from background concentration to very highly polluted (see introduction). The mean Igeo values for all trace elements ranged from 0.3 to 6.4 suggesting background concentration to be very highly polluted. According to Nweke et al. [25] in all the soils, the six metals fall within two Igeo classes based on Muller's interpretation - moderate contamination $(\mathrm{Pb}$ and $\mathrm{Cd})$ and uncontaminated to moderate contamination $(\mathrm{Cu}, \mathrm{Cr}$ and $\mathrm{Zn})$. At $10 \mathrm{~m}$ away from the epicentre of the open dump, the Igeo values for $\mathrm{Cr}$, $\mathrm{Pb}, \mathrm{Zn}$ and $\mathrm{Mn}$ are 6.4, 2.3, 6.1 and 3.8, this indicated that the pollution status of the soil are very highly polluted, moderately polluted, very highly polluted and moderately to highly polluted respectively. At $109 \mathrm{~m}$ away from the epicentre of the open dump, the Igeo values for $\mathrm{Cr}, \mathrm{Pb}, \mathrm{Zn}$ and $\mathrm{Mn}$ had drastically reduced to $2.5,-0.5,1.4$ and 1.4 , showing that the pollution status of the soil are moderately polluted, background concentration, moderately unpolluted and moderately unpolluted respectively.

However, the heavy metal assessment indices are not to be used as the only indicator for soil/sediment quality. Risk assessment relies on the mobile fraction of the metal.

Mobility Factor (MF in \%) of $\mathrm{Cr}, \mathrm{Pb}, \mathrm{Zn}$ and $\mathrm{Mn}$ in the representative aggregate soil samples in the vicinity of NPA Expressway open dump evaluated showed that the MF values ranged from 6\% - 14\%. Zn had the highest MF values of $14 \%$. The low MF values of the metals may be attributed to the high organic matter content of the soils and the textural class of the soil. This is consistent with other reporters [26]. Mobility factor describes the potential mobility of metals in soils as some metals forms are more strongly bound to the soil component than some. High MF values have been reported as symptoms of relatively high liability and biological availability of heavy metals in soils.

Chemical Speciation of the metals as shown in Figure 3 above indicated that the organic matter fraction $\left(\mathrm{F}_{4}\right)$ had the highest\% of $\mathrm{Pb}$. The inputs of $\mathrm{Pb}$ were found in the organic, oxide and carbonate fractions [27]. Fe-Mn oxide fraction $\left(\mathrm{F}_{3}\right)$ had the highest\% of the four metals except $\mathrm{Pb}$. The exchangeable fraction $\left(F_{1}\right)$ had the least $\%$ of the four metals $(0 \%-1 \%)$. The exchangeable fraction is the mobile metal form or phase. This fraction is important because of the high mobility of metals from it to the aqueous phase ${ }^{18}$. Similar observations have been reported by other researchers [28] [29].

The percentage chemical forms of $\mathrm{Cr}, \mathrm{Zn}$ and $\mathrm{Mn}$ showed in Figure 3 are $41 \%, 54 \%$ and $46 \%$ respectively and are found in Fe-Mn oxide fraction $\left(\mathrm{F}_{3}\right)$. $\mathrm{Fe}-\mathrm{Mn}$ oxide fraction had the highest percentage of $\mathrm{Cr}, \mathrm{Zn}$ and $\mathrm{Mn}$. In agreement with these results, several other workers have also reported dominance of the Fe-Mn oxides bound to $\mathrm{Zn}$ [30] [31]. 
Evaluation of the mobile metal forms showed that the most mobile metal in the open dump is $\mathrm{Zn}(63.42 \pm 2.00 \mathrm{mg} / \mathrm{kg})$ while the least mobile metal is $\mathrm{Pb}$ $(0.54 \pm 0.10 \mathrm{mg} / \mathrm{kg})$ and the levels of the mobile metals are above the background sample values.

The mobile metals pools in the soil sample $59 \mathrm{~m}$ away from the open dump indicated that the mobile metals pools have reduced drastically and the most mobile metal in the open dump is $\mathrm{Mn}(7.70 \pm 4.00 \mathrm{mg} / \mathrm{kg})$ while the least mobile metal is $\mathrm{Pb}(0.10 \pm 0.00 \mathrm{mg} / \mathrm{kg})$.

\section{Conclusions}

Mean values of $\mathrm{Cr}, \mathrm{Pb}, \mathrm{Zn}$ and $\mathrm{Mn}$ reported in this study exceeded the background samples values. The heavy metal index (Igeo) indicated that the soils in the vicinity of the NPA Expressway open dump were very highly polluted. A large amount of the metals were bound to the Fe-Mn oxide fraction. $\mathrm{Pb}$ was bound mostly to the organic carbon. The most mobile metal in the vicinity of the open dump was $\mathrm{Zn}$, but at $59 \mathrm{~m}$ away from the open dump, the most mobile metal was $\mathrm{Mn}$, while the least mobile metal was $\mathrm{Pb}$. At about $59 \mathrm{~m}$ away from the open dump, there was a reduction in the mobile metal pools from $63.42 \pm$ $2.00 \mathrm{mg} / \mathrm{kg}$ to $6.70 \pm 2.60 \mathrm{mg} / \mathrm{kg} \mathrm{Zn}, 0.54 \pm 0.10 \mathrm{mg} / \mathrm{kg}$ to $0.10 \pm 0.00 \mathrm{mg} / \mathrm{kg} \mathrm{Pb}$ and $9.62 \pm 0.20 \mathrm{mg} / \mathrm{kg}$ to $7.70 \pm 4.00 \mathrm{mg} / \mathrm{kg} \mathrm{Mn}$.

The open dump induces contamination on the nearer environment by metal mobility. Spatial contamination profile of the heavy metals showed that the levels of the metals decreased with increasing distances from the open dump. Nevertheless, while the impact of the open dump was clear up to the $109 \mathrm{~m}$ covered, the pollution impact of the metals was observed mostly in the soils at very close proximity to the open dump.

\section{Contribution to Knowledge}

This study has provided data and information on:

1) The chemical forms of the heavy metals of environmental concerns in the soils in the vicinity of NPA Expressway open dump.

2) The mobile metal pools which could be absorbable by plants.

3) The spatial contamination profile of the heavy metals in the soils in the vicinity of NPA Expressway open dump, Warri.

\section{Acknowledgements}

I wish to acknowledge the head, central analytical laboratory, Nigerian Institute for Oil Palm Research (NIFOR), Benin city, Edo state, Nigeria for the analytical work. The same acknowledgment also goes to the Tertiary Education Trust Fund (TETFUND) for the grant given towards this research.

\section{Conflicts of Interest}

The authors declare no conflicts of interest regarding the publication of this paper. 


\section{References}

[1] Kalagbor, I.A., Okarahia, F.P., John, O.A. and Okiri, M.A. (2017) Evaluation of Heavy Metals in Some Food Items from Three Markets on the Eleme-Ogoni Highway, Rivers State, Nigeria. Journal of Chemical Society of Nigeria, 42, 12-17.

[2] Abdullahi, Z.B., Gimba, C.E., Omenesa, H. and Lawal, M.A. (2017) Investigation of Some Heavy Metals in Soil and Edible Parts of Spinach Farmlands around Kwari Pond, Kwangila Zaria, Kaduna State, Nigeria. Journal of Chemical Society of Nigeria, 42, 98-105.

[3] Eze, T.C. and Amaeze, N.H. (2016) Microbiological and Heavy Metal Characterization of Soil from an Open Hospital Wastes Dumpsite in Enugu, Nigeria. Asian Journal of Microbiology, Biotechnology and Environmental Sciences, 18, 587-595.

[4] Liu, Q., Liu, Y. and Zhang, M. (2012) Mercury and Cadmium Contamination in Traffic Soil of Beijing, China. Bulletin of Environmental Contamination and Toxicology, 88, 154-157. https://doi.org/10.1007/s00128-011-0441-6

[5] Zhang, X.Y., Liu, F.F., Wong Mike, I.F., Feng, X.L. and Wang, K. (2009) Identification of Soil Heavy Metal Sources from Anthropogenic Activities and Pollution Assessment of Fuyang County, China. Environmental Monitoring and Assessment, 154, 439-441. https://doi.org/10.1007/s10661-008-0410-7

[6] Duong, T.T. and Lee, B. (2011) Determining Contamination Level of Heavy Metals in Road Dust from Busy Traffic Areas with Different Characteristics. Journal of Environmental Management, 92, 554-562. https://doi.org/10.1016/j.jenvman.2010.09.010

[7] Qiao, M., Cai, C., Huang, Y., Liu, Y., Lin, A. and Zheng, Y. (2011) Characterisation of Soil Heavy Metal Contamination and Potential Health Risk in Metropolitan Region of Northern China. Environmental Monitoring and Assessment, 172, 353-365. https://doi.org/10.1007/s10661-010-1339-1

[8] Massas, I., Kalivas, D., Ehaliotis, C. and Gasparatas, D. (2013) Total and Available Heavy Metal Concentrations in Soils of the Thriassio Plain (Greece) and Assessment of Soil Pollution Indexes. Environmental Monitoring and Assessment, 185, 6751-6766. https://doi.org/10.1007/s10661-013-3062-1

[9] Sagi, Y. and Yigit, S.A. (2012) Heavy Metals in Yenicaega Lake and Its Potential Sources: Soil, Water, Sediment and Plankton. Environmental Monitoring and Assessment, 184, 1379-1389. https://doi.org/10.1007/s10661-011-2048-0

[10] Ali, H., Ezzat, K. and Muhammed, A.S. (2013) Phytoremediation of Heavy Metals-Concepts and Applications. Chemosphere, 91, 869-881.

https://doi.org/10.1016/j.chemosphere.2013.01.075

[11] Muller, G. (2001) Schwermetalle in den sedimenten des Rheins-Vera Ėnderungen seit. Umschau, 79, 778-783.

[12] Singh, A.K., Hasnain, S.I. and Benerjee, D.K. (2003) Grain Size and Geochemical Portioning of Heavy Metals in Sediments of the Damodar River. A Tributary of the Lower Ganga, India. Environmental Geology, 39, 90-98. https://doi.org/10.1007/s002540050439

[13] Tessier, A., Campbell, P.G.C. and Bisson, M. (1979) Sequential Extraction Procedure for the Speciation of Particulate Trace Metals. Analytical Chemistry, 51, 844-851. https://doi.org/10.1021/ac50043a017

[14] Cezary, K. and Bal, R.S. (2001) Fractionation and Mobility of Copper, Lead and Zinc in the Vicinity of a Copper Smelter. Journal of Environmental Quality, 30, 485-492. https://doi.org/10.2134/jeq2001.302485x 
[15] National Population Census (2006).

[16] Folson, B.L., Lee, C.R. and Bates, D.J. (1981) Influence of Disposal Environment on Availability and Plant Uptake of Heavy Metals in Dredged Materials. Tech. Re-P EL-81-12 US Army Washington DC.

[17] Nelson, D.W. and Sommers, L.E. (1982) Total Carbon, Organic Carbon and Organic Matter. Methods of Soil Analysis, Part 2, 2nd Edition, ASA, SSSA, Madison, 539-579.

[18] Asagba, E.U., Okieimen, F.E. and Osakpor, J. (2007) Screening and Speciation of Heavy Metals Contaminated Soil from an Automobile Spare Parts Market. Chemical Speciation and Bioavailability, 19, 9-15. https://doi.org/10.3184/095422907X198022

[19] Jackson, M.L. (1960) Soil Chemical Analysis. Prentice-Hall, New York.

[20] Bouyoucos, G.J. (1960) Improved Hydrometer Method for Making Particle Size Analysis of Soils. Agronomy Journal, 54, 464-465. https://doi.org/10.2134/agronj1962.00021962005400050028x

[21] Day, P.R. (1953) Experimental Confirmation of Hydrometer Theory. Soil Science, 75, 181-186. https://doi.org/10.1097/00010694-195303000-00002

[22] Spark, D.L. (2001) Elucidating the Fundamental Chemistry of Soils; Past and Recent Achievements and Future Frontiers. Goederma, 100, 303-319. https://doi.org/10.1016/S0016-7061(01)00026-X

[23] Department of Petroleum Resources (1991) Lagos Environmental Guidelines and Standards for the Petroleum Industry in Nigeria (EGASPIN). 278-281.

[24] Ahmed, A.M.M., Salah, M.A.H. and Ahmed, F.E.A. (2011) Assessment of the Heavy Metals around Two Municipal Solid Waste (MSW) Dumpsites, Egypt. ECO Services International.

[25] Nweke, O.M. and Ukpai, S.N. (2016) Use of Enrichment, Ecological Risk and Contamination Factors with Geoaccumulation Indexes to Evaluate Heavy Metal Contents in the Soils around Ameka Mining Area, South of Abaka Liki Nigeria.

[26] Rahman, F.R., Allan, D.L., Rosen, C.J. and Sadowsky, M.J. (2004) Arsenic Availability from Chromated Copper Arsenate (CCA)-Treated Wood. Journal of Environmental Quality, 33, 173-180. https://doi.org/10.2134/jeq2004.1730

[27] Yusuf, A. (2007) Sequential Extraction of $\mathrm{Pb}, \mathrm{Cu}, \mathrm{Cd} \& \mathrm{Zn}$ in Soils near Ojota Waste Site. Journal of Agronomy, 6, 331-337. https://doi.org/10.3923/ja.2007.331.337

[28] Barona, A., Aranguiz, I. and Elias, A. (1999) Zinc and Copper Distribution in Soils and Their Removal by Chelating Extraction. Journal of Chemical Technology \& Biotechnology, 74, 700-708. https://doi.org/10.1002/(SICI)1097-4660(199907)74:7<700::AID-JCTB103>3.0.CO;2 $\underline{-\mathrm{F}}$

[29] Birch, G., Saika, M. and Owen, C. (2001) The Source of Anthropogenic Heavy Metals in Fluvial Sediments of a Rural Catchment, Cox River, Australia. Water, Air, \& Soil Pollution, 126, 13-25. https://doi.org/10.1023/A:1005258123720

[30] Ahumada, I., Mendouza, J., Navarrete, E. and Ascar, L. (1999) Sequential Extraction of Heavy Metals in Soils Irrigated with Wastewater. Communications in Soil Science and Plant Analysis, 30, 1507-1519. https://doi.org/10.1080/00103629909370303

[31] Pizarro, J., Rubio, A.M. and Castillo, X. (2003) Study of Chemical Speciation in Se- 
diments: An Approach to Vertical Metals Distribution in Rapel Reservoir (Chile). Journal of the Chilean Chemical Society, 48, 45-50.

https://doi.org/10.4067/S0717-97072003000300009 